\title{
The Analysis Of Problem And Threat Of Small And Medium-Sized Enterprizes In Northeast Thailand
}

Thongphon Promsaka Na Sakolnakorn, Prince of Songkla University, Thailand

\begin{abstract}
The objectives of the study are: 1) to study the problems of small and medium-sized enterprises in the northeastern region of Thailand and 2) to analyze the problems of the operation and management of small and medium-sized enterprises in the northeastern region of Thailand. The researcher used a qualitative method with in-depth interviews of 30 entrepreneurs in small and medium-sized enterprises in northeast Thailand. In addition, content analysis was used to analyze this data. The researcher found five problems affecting SMEs in northeast Thailand: 1) public policy and government support, 2) financial support, 3) knowledge capital, 4) labor, and 5) marketing.
\end{abstract}

Keywords: Small and Medium-sized Enterprises, Problem and Threat, Northeast of Thailand

\section{INTRODUCTION}

$\mathcal{O}$ ne of the potential processes to develop the economy in the country is to spread modernity to all regions of the country. When modernization comes to the area economic growth will follow, especially for small and medium-sized enterprises (SMEs), which are very important in developing countries. SMEs are crucial to a developing country because they increase the growth of the economy and industry in the country (Chen \& Rozelle, 1999). SMEs still are one of the important factors that help and support the growth of the economy over the decades. According to data from The Office of Small and Medium-sized Enterprise Promotion (2005), more than 80\% of economic growth takes place due to medium-sized and small enterprises that have emerged in parts of Thailand.

Most developing countries have changed from agricultural to industrial economies. These enterprises are a factor in achieving this outcome and developing the community. In the past, people who were poor and lived in the countryside received help from the government, boosting economic growth in the local area and decreasing the rate of immigration in the countryside due to development.

In the last few decades, industrial development has spread throughout the country. This offers a good chance for medium-sized and small industries to export their products to the international market because these industries have advantages over big industries, including: 1) the communication channel with the market is not complicated and responds to customer requirements promptly; 2) it is easier for small industries to produce goods that conform to consumer demands; and 3) the relationships of medium-sized enterprises are closer than those of big industries, which affects the productive pattern and product standards (Khamanarong, 2002).

In Thailand, the development of industry in the up-country took place 40 years ago when the $4^{\text {th }}$ national economic and social development plan was implemented. This plan was developed to encourage rural development, especially with respect to two notions about up-country industry development: 1) the up-country areas were underdeveloped, so it was necessary to develop and upgrade the areas to compete against developed areas such as Bangkok; and 2) taking advantage of an area's unique resources to spread industry to rural areas, such as water resources, land, and labor costs. These two concepts enabled the spread of industry from the city to rural areas, and medium-sized and small industries were able to grow rapidly and become a potential factor in the development of 
socio-economic well-being (Panpiemras, 1998).

The potential development of enterprises is very important in enabling them to adapt and survive in the world market and to support the free-trade system in the present and future. This is very useful for a country's economy and region. Thus, industry and enterprise administration then turns from minor issues to major issues or core competencies in the organization such as the perspective of the operator's network in the supply chain, tool management, information and technology, and integrated business management, which is very important for the business world. Then industry and enterprise administration becomes the most important tool for business development in the present. Every sector - supplier, distributor, buyer, etc. - has to change and develop its process or strategies to compete against other entrepreneurs who also have high technology. Moreover, business management is a potential factor for the companies that have to survive in the international market. It is very important for a developing country. This is what Thailand has to do as soon as possible. Then, having excellent management will produce better outcomes in terms of quantity and quality, which will upgrade the country's industrial standard for the future as well.

The data of the Office of Small and Medium-sized Enterprise Promotion (2008) reveal that there are 818,182 (28.9\%) enterprises in Bangkok and the surrounding area. The area with next-highest number is the northeastern region, where there are 717,990 (25.4\%) enterprises. There are 451,247 (16.2\%) in the north, 365,506 $(12.9 \%)$ in the south, 199,604 (7.1\%) in the east, 122,811 (4.3\%) in the west, and 104,147 (3.7\%) in the central region, as shown in Table 1:

Table 1: The number of medium-sized and small enterprises by region in Thailand in 2008

\begin{tabular}{l|c|c}
\hline \multicolumn{1}{c}{ Region } & Number of SMEs & Percentage $(\%)$ \\
\hline Bangkok and surrounding area & 818,182 & 29.4 \\
\hline Northeastern & 717,990 & 25.8 \\
\hline North & 451,247 & 16.2 \\
\hline South & 365,506 & 13.2 \\
\hline East & 199,604 & 7.2 \\
\hline West & 122,811 & 4.4 \\
\hline Central & 104,147 & 3.7 \\
\hline Total & $\mathbf{2 , 7 7 9 , 4 8 7}$ & $\mathbf{1 0 0}$ \\
\hline Soun
\end{tabular}

Source: The Office of Small and Medium-sized Enterprise Promotion, 2008

As Table 1 shows, outside of Bangkok and the surrounding area, the northeastern region has the most enterprises compared to other regions of Thailand. This is a factor that propels and develops the regional economy and also creates employment, which affects local labor. The GDP of SMEs in 2008 was 3,446,589.2 million Baht or $37.9 \%$ of GDP (The Office of Small and Medium-sized Enterprise Promotion, 2009). In addition, the study of Promsaka Na Sakolnakorn et al. (2010) suggests that outsourcing and subcontracting is one strategy for SMEs to run their business, and it is related to developing regions through economic growth and a high rate of employment.

However, SMEs do not offer only advantages and boost the economy; a lot of SMEs still face obstacles. Sakulsurarat (2008) studied the direction of medium-sized and small enterprises, finding that $50 \%$ of the sample operated as limited companies and were managed by Thais. They are not members of government and private organizations. More than $80 \%$ have operated for more than 5 years. Their assets were 10-50 million Baht and with 10-50 employees. However, the problems that affect their businesses are marketing, competition, finance and accounting, government policy, staff, management and administration, and production and technology.

In addition, according to the study conducted by Promsaka Na Sakolnakorn et al. (2009), who studied SMEs in the textile industry, they found that the entrepreneurs always face financial problems. It is difficult to request credit from financial institutions. They still lack knowledge about the process of seeking loans, and they also have a problem related to the culture in the region. This was supported by the work of Promsaka Na Sakolnakorn et al. (2008), which stated that employees in northeastern Thailand must have long holidays, especially for big festivals such as the New Year holiday, the important Buddha days, and so on. In addition, turnover rates are high because 
employees must leave factories to work on their farms during the agriculture season.

Nimman Patcharin (2009) discussed the situation of the medium-sized and small enterprises in 2009, identifying the factors that affect business operations in negative ways: 1) the Thai economy, particularly with respect to investment, confidence, and export capability; 2) political issues; SMEs are concerned about prolonged conflict that affects confidence in tourism and the Thai economy, which may cause consumers to save their money rather than spend it; 3) domestic consumer behavior, which affects business due to concerns about political issues; 4) the world economy; and 5) domestic competition, as big and multi-national enterprises may have more market share, causing SMEs to perform poorly in the market.

In solving the problems of SMEs, studying is still important because business is dynamic; the competitors, business environment, and world business change every day. As the researcher mentioned before, the question asked by this study is what the problems of SMEs are in the northeastern region of Thailand. The objectives of the study are 1) to study the problems of small and medium-sized enterprises in the northeastern region of Thailand, and 2) to analyze the problems of the operation and management of small and medium-sized enterprises in the northeastern region of Thailand. The result of this study is going to provide direction in developing the operation of SMEs in the northeastern region of Thailand, and it will serve as a case study for other regions that are similar to northeastern Thailand.

\section{RESEARCH METHODOLOGY}

In this paper, the researcher used a qualitative method employing in-depth interviews. The researcher spent six months on field work research between August of 2009 and January of 2010. In-depth interviews (informal interviews) lasting from 30 minutes to two hours were conducted with 30 entrepreneurs in small and medium-sized enterprises in northeastern Thailand. There were 11 entrepreneurs in the Khon Kaen province, 3 in the Nakhon Ratchasima province, 3 in the Udon Thani province, 2 in the Chaiyaphum province, 2 in the Roi Et province, 2 in the Buri Ram province, 2 in the Kalasin province, 2 in the Ubon Ratchathani province, 1 in the Yasothon province, and 1 in the Surin province. In addition, for ethical purposes, the researcher will not provide the names of entrepreneurs; however, locations such as villages, districts, and provinces are provided.

In addition, the researcher used content analysis to analyze the data gathered from the in-depth interviews, along with descriptive statistics to present the results of the analysis.

\section{RESULTS AND DISCUSSION}

This study categorized the industries into the 4 categories of the Office of Small and Medium-sized Enterprise Promotion (2007) as follows:

1) Manufacturing sector: small enterprises in the manufacturing sector should have no more than 50 employees and an asset value, excluding land, that does not exceed 50 million Baht. Medium-sized enterprises in the manufacturing sector should have 51-200 employees and an asset value, excluding land, that does not exceed 200 million Baht.

2) Wholesale sector: small enterprises in the wholesale sector should have labor no more than 25 employees and employees and an asset value, excluding land, that does not exceed 50 million Baht. Medium-sized enterprises in the wholesale sector should have 26-50 employees and an asset value, excluding land, that does not exceed 100 million Baht.

3) Retail sector: small enterprises in the retail sector should have labor no more than 15 employees and employees and an asset value, excluding land, that does not exceed 30 million Baht. Medium-sized enterprise in the retail sector should have 16-30 employees and an asset value, excluding land, that does not exceed 60 million Baht, and

4) Service sector: small enterprises in the service sector should have no more than 50 employees and employees and an asset value, excluding land, that does not exceed 50 million Baht. Medium-sized enterprises in the service sector should have 51-200 employees and an asset value, excluding land, that does not exceed 200 million Baht. 


\section{Results of In-depth Interviews}

\subsection{SMEs in the manufacturing sector}

The textile industry has spread throughout the northeastern region. This research studies the textile community group in the Non-Poor village in the Baan-Kaew District of the Chaiyaphum Province. This group started their work with 100,000 Baht as the first investment, and now the business property is currently worth 500,000 Baht. There are 14 employees who work in the factory. Their function is to sew and produce shirts and sweaters, and they buy raw materials themselves. The interview showed that the operation's problems are caused by, first, the high level of competition among entrepreneurs engaged in the same business. For instance, to compete against others, some entrepreneurs decrease the selling price. Then, though they can sell the product, they earn little profit. The second problem is a lack of marketing knowledge; entrepreneurs do business by using their experiences and rarely learn new process that may lead to more profits for them. The third problem is financial management such as giving credit to customers. They give credit based on trust without documents, resulting in being in arrears. The fourth problem is a lack of support from the government.

One community enterprise produces round-necked, sleeveless, collared shirts in the Dong Pikul village in the Chiang Khan district of the Roi-Et province. This industry is a sub-contracting industry. They are hired by factories in Bangkok. Family members produce the shirts in their households. Currently, there are 14 employees. According to the interview, the weak point of being a subcontractor is that they do not produce their own products. If a factory from Bangkok does not hire them, they have no work to do. Furthermore, there is a lack of management knowledge and product development. It is a problem for the subcontractor in creating their own product.

One of the interesting enterprises is the awning industry in the Non-bor village in the Phra Yuen district of the Khon Kaen province. This industry has 200 entrepreneurs. The interesting details derived from the interview are as follows: 1) high competition in the awning market - there are 200 entrepreneurs in the village as well as others from nearby villages; 2) high cost of transportation, especially gas costs, which fluctuate all the time, but the suppliers cannot change the product price; 3 ) there are similar product that offer more advantages than the product that the entrepreneurs produce; and 4) there is a lack of management knowledge such as knowledge about marketing, finance, packaging, and so on.

The next enterprise involves shirt production in the Phu Wiang district of the Khon Kaen province. This is medium-sized enterprise with 60 employees. Most of the stakeholders are Chinese who invested in and established the factory as a subcontractor. They are hired from Chinese factories to produce the shirts for export. According to the interview with the Thai head of labor, this factory is just a sub-contract production, so they have no problem with marketing or ordering. The problems they face include the lack of employees in the surrounding area. Most employees move to work in Bangkok and the surrounding area. Second, since they lack young employees, the factory has to recruit the elderly to work, and third, when the harvest season comes, employees usually stop their work in the factory and return home to do agricultural work, so there are not enough employees during that season.

A leather enterprise that produces bags and belts in the Kumuang district of the Buri Ram province is a small operation, set up by community members. According to the interview, its problems are 1) marketing, such as promotion and public relations; 2) a lack of government support; and 3) a lack of special knowledge such as packaging and new technology.

A furniture enterprise in the Pon district of the Khon Kaen province is a medium-sized enterprise with 90 employees. The study found that government policy is the essential problem for the industry. For instance, the government does not change or adapt the modernity policy, especially in the case of the policy of importing raw materials from overseas. Another problem involves management; due to the high level of investment in machinery, entrepreneurs cannot develop production process as well as they would like to. Third, while the government supports the enterprise in the financial process, in fact, it is difficult to request credit from a financial institution.

An artificial flower enterprise in the Lerng Nok Tha district of the Yasothon province has encountered the following problems: 1) a lack of government support; 2) insufficient knowledge of marketing and a limited selling 
channel; 3) high competition in the market; and 4) a lack of funds, which makes it difficult to develop their product.

The last example in the manufacturing sector is a drinking water enterprise in the Nakorn Ratchasima province. This small enterprise consists of 32 employees. According to the interview, 1) there are many competitors in the market; 2) the high cost of transportation directly affects the selling cost; 3) it is difficult to develop the business due to a lack of funds, and the government does not provide enough support; and 4) the employee turnover rate is high, especially in the rainy season.

\subsection{SMEs in the wholesale sector}

The first example of a wholesale enterprise is a garment shop in Muang district of the Udon thani province. The obstacles of the business are the following: 1) circulation is down since the political revolution in 2006. The government has tended to focus on political issues more than economic issues. 2) The birth of the major wholesale superstores has directly affected local businesses because the superstores are more convenient and sell goods at cheaper prices than local stores. 3) There is no policy to protect local business, but the government supports the policy for overseas businesses to invest in Thailand.

The next example is an enterprise that sells military clothes and adventure tools in the Muang district of the Udon thani province. The problems in the business are: 1) Chinese products are going to claim the market because of lower costs. 2) Even though the profit of this business is small, they still pay a high price for the good location.

At a consumer products wholesale enterprise in the Muang district of the Kalasin province, there are 18 employees. According to the interview, 1) the major wholesale superstores sell products at lower prices than local stores, and this causes local stores to collapse. 2) The central government has no policy to protect local business, though it supports the policy for overseas businesses to invest in Thailand. 3) The laws and regulations in Thailand are outdated.

According to the interview with a garment wholesaler in the Muang district of the Khon Kaen province, 1) there are many competitors in the market. 2) The trends change all the time. 3) Due to the convenience of transportation and low ticket prices, consumers will buy goods in Bangkok.

The next example is a backrest pillow, drapery, and bedclothes wholesaler in the Yangtalad district of the Kalasin province. This enterprise has 15 employees, and the interview indicated that 1) circulation is directly relates to the country's economic status. 2) The government does not support them in spreading goods to the international market, even though there is a lot of demand and a large number of buyers on the international market. 3) There is a lack of skillful employees to produce the products because they mostly move to work in the large industrial sector. 4) The management of production costs is challenging because the costs increase constantly, but it is difficult to increase the selling price.

Regarding a wholesaler in the Muang district of the Mukdahan province that imports consumer products from China and Vietnam, the study found the following problems: 1) poor circulation due to economic issues; 2) a decrease in the number of tourists due to the political conflict; and 3) high competition in the market.

The last example is a consumer products wholesaler in the Muang district of the Ubon Ratchathani province. This is a small enterprise that employs 12 employees. The study found the following problems: 1) the damaging effect of the major wholesale superstores and large convenience stores such as Tesco Lotus and Big-C; 2) a lack of management knowledge; 3) a lack of funds to develop the enterprise; and 4) a lack of inspiration to develop the enterprise.

\subsection{SMEs in the retail sector}

One retail enterprise that the researcher is interested in is a construction equipment business employing 23 people in the Banped sub-district of the Khon Kaen province. According to the interview with the owner, 1) it is difficult to recruit employees, and the turnover rate is high, especially in the agriculture season. 2) Sales of 
construction equipment are related to the status of the economy and investment by the government in infrastructure, and 3) even though the government supports the enterprise in the financial process, it is difficult to request credit from a financial institution.

A clothes retail shop in the Muang district of the Khon Kaen province is a family business with 2 branches. According to the interview, the problems are: 1) high competition in the market; 2) trends that change constantly; 3 ) little profits; 4) the high cost of the good location; 5) song copyrights. Officials usually ask for bribes, even when the owner buys a song legally.

Like the clothing shop in the Khon Kaen province, a clothing shop in the Muang district of the Udon Thani province has similar problems. Moreover, the researcher found that the entrepreneur does not have knowledge of business development and suffers from a lack of government support.

Next is a miscellaneous shop in the Muang district of the Chaiyaphum. The researcher found that 1) the birth of the big wholesale superstores has directly affected local business. 2) The entrepreneur does not have knowledge of business management. 3) The super-convenience stores like 7-11 are also big competitors. 4) There is a lack of funds to develop the business.

Regarding a computer equipment business in the Muang district of the Khon Kaen province, the interesting points include 1) high competition in the market. 2) The producers usually release new models of the equipment. 3) This business has to use lots of funds for investment, so it is difficult to compete against big entrepreneurs. 4) The cost of the good location is high. 5) The process of requesting credit from a financial institution complicated. 6) It is difficult to recruit skillful employees, and the turnover rate is high.

Next is an agricultural equipment enterprise in the Muang district of the Roi-Et province. This is a small enterprise that employs 6 people. According to the interview, 1) agriculturalists will buy equipment depending on the income they have received. 2) The circulation will be higher if the government focuses more on agricultural policy. 3) Employee are often absence, and the turnover rate is high, especially in the harvest season. 4) Due to Thailand's free-trade policy, Chinese products are imported in greater amounts and more cheaply than local products.

For a consumer goods retail shop in the Muang district of the Surin province, the problems include: 1) the lack of business management, so it is difficult to compete against modern shops. 2) There is a lack of funds, and the process of requesting credit from a financial institution is very complicated. 3) The cost of goods is higher than in big retail stores, which may cause a customer to decide to buy at a big store.

The last retail shop is a furniture shop in the Muang district of the Khon Kaen province. The researcher found 1) a high level of competition in the market; 2) a lack of financial support because the size of the enterprise is small, and 3) high product prices compared to the big retail shops.

\subsection{SMEs in the service sector}

Service enterprise is the general enterprise in Thailand. The researcher interviewed a Thai massage entrepreneur in Nakorn Ratchasima. This business is a small enterprise employing 7 people. 1) The good location is expensive. 2) The employee turnover rate is high, and there is a lack of skillful massagers. 3) There is a high level of competition in the market. 4) There is a lack of funds for business development. 5) The owner operates the business using his/her experiences. This will limit the opportunities to develop the business.

Another example is a Thai massage shop in the Muang district of the Ubon Ratchathani province. The researcher found that 1) the employee turnover rate is high, and there is a lack of skillful massagers. 2) There has been an increase in the number of competitors, especially brand-name entrepreneurs. 3) It is difficult to request credit from a financial institution, and there is a lack support from the government. 4) The good location is expensive. 
The next example is a travel and ticketing business that employs 5 people in the Muang district of the Buri Ram province. According to the interview, 1) the number of tourists going to Cambodia through the Buri Ram and Surin provinces has decreased because of the conflict between Thailand and Cambodia. 2) The economic crisis has directly affected the tourism business. 3) It is difficult to get credit from a financial institution. 4) There is a lack of support from the government.

Internet cafés are popular businesses in Thailand. The researcher studied an Internet café in the Muang district of the Khon Kean province. This café is a family business. The study found that 1) this business is full of entrepreneurs because it is easy to start such a business. 2) There are lots of problems that arise from laws, regulations, and copyrights. 3) There are high costs due to the development of technology. 4) There are too many expenses involved in running such as business such as the licenses issued by many official departments. Moreover, these businesses face bribery demands.

Internet café entrepreneurs in the Muang district of the Nakorn Ratchasima face the same problems of those in Khon Kaen. According to the interview, 1) there is a high level of competition in the business, profits are low because most of the entrepreneurs use discount promotions to convince customers to buy. 2) The cost of copyrights from producers and officials s high. 3) This business has to use funds continually, but they do not get support from the government.

The next enterprise is a Chinese restaurant in the Muang district of the Khon Kaen province. This is a small enterprise employing 5 people. The study found that 1) a good location is expensive. 2) The employee turnover rate is high, and it is difficult to find Thai employees, 3) It is difficult to obtain bank loans.

The last example is a laundry service in the Muang district of the Khon Kaen province. According to the interview, 1) the laundry service usually faces the problem of a decreasing number of customer because of the current economic crisis. 2) The employee turnover rate is high, and it is difficult to find employees. 3) There is a lack of support from the government. 4) It is difficult to request credit from financial sources.

\section{The Analysis of Problems and Threats for Small and Medium-sized Enterprises in Northeast Thailand}

Based on the study involving in-depth interviews of 30 entrepreneurs in small and medium-sized enterprises in northeast Thailand, the researcher can analyze the problems and threats for small and medium-sized enterprises as follows:

1) The Problem of Public Policy and Government Support

Hall and Jenkins (1995) suggest that public policy is government activities and that the government must be concerned with economic activities; social norms; culture; and the political structure, characteristics, and government planning, which affects the policy concepts and processes of government. Almost all SME entrepreneurs in northeastern Thailand have received a little support from the government; however, such policies have not continued. In addition, the rule of law is not convenient to SMEs, as the government uses public policy to supported large enterprise. SMEs also face a problem with respect to financial support from financial institutions, especially from those under government control. In addition, the government has implemented a good public policy regarding the financial load for SMEs; however, it is difficult in practice because it is has a lot of conditions and documentation requirements. Furthermore, some businesses such as Internet cafés and game shops have problems involving government agencies such as police and copyright agencies, which often use their authority to make money from entrepreneurs illegally.

2) The Problem of Financial Support

SMEs lack access to financial support because of they do not know about accounting systems and how to write their business plan, and most of them do not have enough assets to guarantee their bank loans. This financial problem pushes them to borrow money to support their businesses from underground capitalists at high interest 
rates; according to my survey, these interest rates are at least 5 percent per day, which is an infringement of financial law. This problem causes a lack of business development. In addition, this issue is related to several problems such as lack of money, preventing them from setting up their business in good locations because it is expensive. Another problem is technology acquisition, as technology is one issue that prevents entrepreneurs in small and medium-sized enterprises in northeast Thailand from competing with large enterprises and overseas competitors. The financial problem is related to this issue because without money, entrepreneurs cannot invest in new technology or machinery. In addition, information technology such as the Internet and Web pages are available to only a few entrepreneurs for business communication because most entrepreneurs are located in rural areas or lack knowledge of technology.

3) The Problem of Knowledge Capital

Gorman, Rosa, and Faseruk (2005) suggest that knowledge-based business is important for enterprises; for example, some large enterprises have created training centers to train their employees. Entrepreneurs, especially in SMEs in northeastern Thailand, lack knowledge capital such as knowledge of business administration because they manage their business based on their own experiences, and most of them are not well-educated. Thus, this problem affects their marketing management, organization development, information management, and so on, which makes them uncompetitive. In addition, SMEs face a limitation of information, which makes them slow to develop their businesses.

\section{4) The Problem of Labor}

Labor is a problem that affects business management. It is difficult to find skill workers in the northeast region because they must move away to work in the central region or another region where they can make more money, and many workers in the northeast like to work in large enterprises; this issue is reflected in the study of Kongmanila and Takahashi (2009), who suggest that in Laos, skilled labor is an important factor for entrepreneurs. In addition, the workers in the northeast must leave their work at enterprises to work on farms during the agriculture season.

5) Lack of Marketing Management

The researcher found that most SMEs have problems with marketing management, and that they operate their businesses based on their own experiences, which prevents them from creating strategy and marketing promotions to compete with large and/or multinational enterprises. In addition, they have problems such as a lack of knowledge about product design, product development, developing the right marketing strategy, marketing promotion, and use of marketing research as a marketing tool. The lack of a marketing budget and marketing knowledge is an obstacle in developing their businesses.

\section{CONCLUSION}

The researcher identified 5 problems of SMEs in northeastern Thailand: 1) public policy and government support; 2) financial support; 3) knowledge capital; 4) labor; and 5) marketing. Having identified these five problems, entrepreneurs must endeavor to solve problems by developing their skills and finding a way to strengthen the business of SMEs and develop their businesses to be more competitive. In addition, based on an idea of the researcher, if SMEs adapt to become subcontractors for large enterprises such as multinational companies, they develop and run their businesses in stability because some outsourcers not only outsource some production to subcontractors but also provide management knowledge to subcontractors.

For future study, a quantitative method employing a questionnaire should be used to survey entrepreneurs in small and medium-sized enterprises in northeastern Thailand to confirm the results of this study. In addition, the development of SMEs is also an interesting area for future research. 


\section{ACKNOWLEDGEMENTS}

The author would like to thank the 30 entrepreneurs in northeastern Thailand for their support and kindness to the researcher in agreeing to participate in in-depth interviews.

\section{AUTHOR INFORMATION}

Dr. Thongphon Promsaka Na Sakolnakorn is a lecturer of the Faculty of Liberal Arts at the Prince of Songkla University, Thailand. He received his first Ph.D. in development science from Khon Kaen University, Thailand, and his second doctoral degree in Ancient Indian and Asian studies from Magadh University, India. He specializes in outsourcing management, organization development, and SME management. He has authored published articles about outsourcing management, organization development, and SME management issues. His contact e-mail is: thongphon.p@psu.ac.th, deaw_t@hotmail.com.

\section{REFERENCES}

1. Chen, H., and Rozelle, S. 1999. Leaders, managers, and the organization of township and village enterprises in China. Journal of Development Economics, 60, 529-557.

2. Gorman, Gary G., Rosa, Peter A. \& Faseruk, A. 2005. Institutional Leading to Knowledge Based Businesses. Journal of Business Venturing, 20, 793-819.

3. Hall, C.M \& Jenkins, J. 1995. Tourism and Public Policy. U.K., London: Routledge.

4. Khamanarong, S. 2002. The marketing diversification of SMEs administration in Thailand. (Research report No. 138). Japan: Economic Research Center, Nagoya University.

5. Kongmanila, X. \& Takahashi, Y. 2009. Determinants of Subcontracting in Lao Garment Industry. Contemporary Management Research, 5(3), 273-286.

6. Nimman Patcharin, N. 2009. Several Problem of SMEs Trend Decrease in Five Year. Retrieved on March 10, 2010. From, http://www.manager.co.th/SMEs/ViewNews.aspx?NewsID=9520000040879.

7. Panpiemras, K. 1988. Rural industrialization in Thailand. Bangkok: National Economic and Social Development Board.

8. Promsaka Na Sakolnakorn, T., Khamanarong, S., Khamanarong, K. and Imtavil, V. 2008. Causal Variables Affecting Rural Industry Outsourcing in Northeast Thailand. International Business \& Economic Research Journal. 7(7), 77-82.

9. Promsaka Na Sakolnakorn T, Aim-Im-Tham, S. \& Khamanarong S. 2009. Management Strategy for Administration of Textile Industries in Developing Country: Case Study Thailand. Journal of Business Case Studies. 5(3), 37-44.

10. Promsaka Na Sakolnakorn, T., Khamanarong, S., Khamanarong, K., Imtavil, V. \& Overton, J. 2010. Industry Outsourcing and Regional Development in Northeast Thailand. Asia Pacific Viewpoint. 51(1), 105-111.

11. Sakulsurarat, S. 2008. Mission Integrated of Small and Medium Enterprises in Public and Private Sector Between 2002 - 2007. Retrieved on March 10, 2010. from, library.dip.go.th/ multim/edoc/08732.doc.

12. The Office of Small and Medium Enterprises Promotion. 2005. SMEs Situation Report 2005 Trend to 2006. Retrieved on March 09, 2010. from, http://cms.sme.go.th/cms/c/portal/ layout?p 1_id=22.220.

13. The Office of Small and Medium Enterprises Promotion. 2007. SMEs Situation Report 2007 Trend to 2008. Retrieved on March 09, 2010, from, http://cms.sme.go.th/cms/c/portal/ layout?p 1 id=22.360.

14. The Office of Small and Medium Enterprises Promotion. 2008. SMEs Situation Report 2008 Trend to 2009. Bangkok: Tangsadouk. 
NOTES 